\title{
Memahami Penelitian Kualitatif Dalam Akuntansi
}

\author{
Zul Azmi, Abdillah Arif N, Wardayani \\ Universitas Sumatera Utara \\ zulazmi@umri.ac.id; badiqq@yahoo.com; cici_wardayani@yahoo.co.id
}

\begin{abstract}
This paper aims to describe qualitative research that began to develop in the field of accounting. Qualitative descriptive method is used to collect data and describe qualitative research in accounting. The results of research can add to the understanding of qualitative research in accounting. Qualitative research provides freedom from the limit of the deductive hypothesis testing obsession that allows to investigate issues and questions that have been neglected by the dominant research paradigm. Assimilating accounting disciplines with other disciplines may open up opportunities for qualitative research.
\end{abstract}

Keywords: qualitative, accounting

\begin{abstract}
Abstrak
Paper ini bertujuan mendeskripsikan penelitian kualitatif yang mulai berkembang pada penelitian di bidang akuntansi. Metoda kualitatif deskriptif digunakan untuk mengumpulkan data dan menggambarkan penelitian kualitatif dalam akuntansi. Hasil penelitian dapat menambah pemahaman penelitian kualitatif dalam akuntansi. Penelitian kualitatif memberi kebebasan dari batas obsesi pengujian hipotesis deduktif yang memungkinkan menginvestigasi isu dan pertanyaan yang hingga kini terabaikan oleh paradigma penelitian dominan. Asimilasi disiplin akuntansi dengan disiplin lainnya dapat membuka peluang untuk riset kualitatif.
\end{abstract}

Kata kunci: kualitatif, akuntansi

Diterima: 24 November 2017; Revisi: 2018; Disetujui: 2018 


\section{PENDAHULUAN}

Metode penelitian dapat diklasifikasi menjadi penelitian kualitatif dan kuantitatif. Penelitian kualitatif menggunakan data kualitatif seperti wawancara, data observasi partisipan dan data dokumen untuk memahami dan menjelaskan fenomena sosial. Penelitian kualitatif sering mendapat kritik karena cenderung lebih subjektif daripada penelitian kuantitatif, sehingga kurang ilmiah (Parker, 2008). Analisis data kualitatif dapat menjadi ilmiah seperti pada analisis statistikal data kuantitatif dengan penggunaan metoda. Penggunaan metoda tertentu dapat mengarahkan dan membuktikan bahwa dua atau lebih peneliti bisa menghasilkan simpulan yang mirip pada riset yang sama (Samkin dan Schneider, 2008).

Pada beberapa peneliti, penelitian kualitatif dianggap tidak cukup untuk tujuan penelitian sehingga peneliti enggan untuk mengunakannya (Basri, 2014). Dampaknya para peneliti di kampus menjadi kurang terbiasa menggunakannya dibandingkan dengan penggunaan penelitian kuantitatif. Meskipun demikian, jika mengacu pada perkembangan publikasi penelitian ilmiah di jurnal terkemuka pada disiplin akuntansi dan manajemen, tampak bahwa publikasi penelitian kualitatif mulai menunjukkan perkembangan signifikan (Parker, 2014), meskipun publikasi penelitian kuantitatif masih menjadi yang paling luas digunakan (Basri, 2014). Saah satu argumen yang menjelaskan semakin berkembangnya penelitian kualitatif adalah ia telah memberi kebebasan pada literatur dari batas-batas obsesi pengujian hipotesis deduktif, yang memungkinkan menginvestigasi isu-isu dan pertanyaan yang hingga kini terabaikan oleh paradigma penelitian dominan. Riset kualitatif memberi peluang pendekatan interdisipliner untuk permasalahan yang kompleks, merangkul skenario holistik yang tidak dapat dengan baik dipecahkan melalui pemodelan abstrak. Penelitian kualitatif mesti dipahami dengan sudut pandang yang berbeda dari pendekatan kuantitatif. Oleh karena itu, paper ini berupaya menjelaskan bagaiman memahami penelitian kualitatif terutama pada penelitian akuntansi dan manajemen, sehingga paper ini diorganisir menjadi beberapa bagian yaitu konsep riset kualitatif, mengapa menggunakan riset kualitatif, dan bagaimana proses riset kualitatif serta ditutup dengan simpulan. 


\section{METODE}

Penelitian ini bersifat deskriptif kualitatif dengan pendekatan literature review. Metoda dilakukan dengan cara mengumpulkan data, menyusun, dan mendeskripsikan sehingga diperoleh hasil berupa gambaran yang jelas tentang perkembangan penelitian kualitatif pada bidang akuntansi.

\section{HASIL DAN PEMBAHASAN}

Penelitian kualitatif merupakan metode dengan beraneka segi fokus yang meliputi suatu interpretif, konstruktif, pendekatan naturalistik pada subjeknya (Trumbull \& Watson, 2010). Hal ini bermakna penelitian kualitatif mempelajari sesuatu pada sudut pandang alamiahnya, menerjemahkannya, dan melihat fenomena dalam hal makna yang dipahami manusia. Dengan kata lain penelitian kualitatif dapat mempelajari sisi nyata dunia, menemukan bagaimana orang mengatasi sesuatu dan berkembang dalam situasi tersebut yang menggambarkan kehidupan manusia kontekstual (Yin, 2011, p.6). Denzim \& Lincoln (1994), Patton (2002) menuturkan bahwa penelitian kualitatif meliputi studi yang menggunakan dan mengumpulkan beragam studi kasus bahan empiris, pengalaman pribadi, introspektif, ceritera kehidupan, wawancara, observasional, historikal, interaksional, dan teks visual yang menggambarkan peristiwa rutinitas dan problematis dan makna dari kehidupan individual (Trumbull \& Watson, 2010; p.62).

Penelitian kualitatif memiliki diversitas karena ia relevan pada disiplin dan profesi yang berbeda-beda. Yin $(2011$, p.7) menjelaskan keragaman pandangan pada penelitian kualitatif ini dapat dicirikan pada lima hal yaitu: Pertama, mempelajari makna kehidupan manusia melalui kondisi dunia nyata. Interaksi sosial akan terjadi dengan gangguan minimal oleh prosedur-prosedur penelitian artifisial dan orang bebas berkata apa yang mereka mau katakan tanpa batasan untuk merespon kuisioner yang telah dirancang oleh peneliti. Demikian pula, orang tidak dihambat dengan batas-batas dari laboratorium atau keadaan yang seperti laboratorium. Kedua, penelitian kualitatif berbeda karena kemampuannya 
menunjukkan pandangan dan perspektif partisipan dalam suatu studi. Menangkap perspektifnya mungkin menjadi tujuan utama studi kualitatif. Kejadian-kejadian dan gagasan yang masuk dari riset kualitatif dapat mununjukkan makna dari kejadian nyata yang dialami seseorang, bukan nilai, prasangka, atau arti yang ada di benak peneliti. Ketiga, penelitian kualitatif mencakup kondisi kontekstual dalam kehidupan manusia. Keempat, memberikan wawasan tentang konsep yang ada atau yang muncul yang mungkin dapat membantu menjelaskan perilaku sosial manusia. Kelima, berusaha menggunakan banyak sumber bukti daripada mengandalkan satu sumber saja.

Terdapat beberapa bentuk metode kualitatif yang dapat dipakai diantaranya fenomenologi, grounded theory, etnography, studi kasus, dan biographic (Trumbull dan Watson, 2010). Pemilihan metode bergantung pada sifat dan cakupan masalah yang hendak diinvestigasi, termasuk pelatihan dan pengalaman peneliti, daya penerimaan individual pada bidang yang di kaji, tipe partisipan yang dipilih dan tekniknya. Fenomenologi merupakan ilmu yang mempelajari perilaku dan peristiwa pada manusia yang secara sistematis mencari penjelasan untuk arti dan esensi suatu fenomena dan didesain untuk memperoleh pengetahuan melalui pengalaman kehidupan manusia. Grounded theory dirancang untuk mengembangkan atau membangun teori yang berkaitan dengan fenomena pada studi. Dengan kata lain, teori dikembangkan dari data yang ada. Grounded theory pertama dikembangkan oleh dua orang sosiolog yaitu Barney Glasser dan Anselm Strauss pada tahun 1967 (Boadu dan Sorour, 2015). Etnography menurut Haris (1968) merupakan deskripsi dan interpretasi dari sebuah kultural atau kelompok sosial atau sistem (Trumbull dan Watson, 2010). Dengan demikian, pada etnografi peneliti hendaklah memahami dengan baik antropologi kultural dan memiliki pemahaman komprehensif pada sistem kultural yang di teliti. Penggunaan data etnografi bermanfaat pada penelitian Oever dan Martin (2015) untuk menginvestigasi peran dan taktik manajerial dalam pengambilan keputusan pada kasus perubahan model bisnis.

Beberapa penerapan penelitian kualitatif pada disiplin akuntansi dan manajemen tampak pada Forgarty dan Jones (2014) yang menjelaskan mengapa 
profesional pajak di USA selalu berada pada posisi ambigu, Stone et al., (2015) menjelaskan sistem pengendalian manajemen eBay, Cohanier (2014) mengenai sistem manajemen kinerja, Basri, Nabiha \& Madjid (2016) yang meneliti akuntansi dan akuntabilitas pada organisasi religius.

Perbedaan antara riset kuantitatif dan kualitatif menunjukkan keunggulan dan kelemahannya. Riset kualitatif seperti karakteristiknya dapat menjelasakan mengapa memilih penelitian kualitatif. Hoepfl (1997,p.49) menjelaskan karakteristik riset kualitatif yaitu menggunakan setting alamiah, bertindak sebagai human instrument dalam pengumpulan data, menggunakan analisis data induktif, bersifat deskriptif, menggabungkan bahasa ekspresif dan menggunakan rekaman suara kedalam teks, memiliki karakter interpretif, memperhatikan hal yang idiosyncratic dan pervasif, mencari keunikan masing-masing kasus, memiliki desain yang muncul dan periset fokus pada proses yang muncul ini sebagaimana dengan riset outcome atau hasil, dinilai menggunakan kriteria khusus untuk kepercayaan (trustworthiness) (Basri, 2014). Alasan lain penggunaan kualitatif yaitu karena persoalan alat ukur yang mengkonversi ke angka akan menjadi problematis jika dilakukan pada pengalaman manusia. Dalam hal ini pilihan penelitian kuantitatif menjadi kurang relevan. Demikian juga dengan manipulasi studi eksperimen terhadap manusia yang menjadi perdebatan karena menyangkut etik.

Pertanyaan mengapa menggunakan kualitatif, menjadi rasional ketika para manajer hendak mengambil keputusan atau menerapkan intervensi organisasional, karena manajer kerap lebih menyukai menggunakan pengalamannya, intuisinya, atau jaringan sosial daripada basis ilmiah (Denyer dan Tranfield, 2006). Sedangkan dalam disiplin akuntansi, ia bergantung pada sejumlah faktor yang saling terkait, termasuk adanya asimilasi gagasan dari disiplin lainnya. Misalnya, penelitian pada akuntansi sektor publik banyak berhubungan dengan studi kasus. Meskipun pada bidang keuangan, metoda kuantitatif mendominasi dalam analisis database statistik yang secara luas digunakan untuk menunjukkan kinerja di pasar modal, namun selalu ada sisi lain 
yang membutuhkan riset kualitatif. Misalnya pada riset Holland yang fokus pada keterkaitan antara perusahaan dan institusi yang mengatur regulasi pasar, dia menggunakan wawancara dan studi kasus untuk menggali isu yang berkaitan dengan pengungkapan sukarela, informasi sensitif harga, dan manajemen dana (Lee dan Humphrey, 2006). Penelitian kualitatif juga dilakukan oleh Basri, Nabiha dan Madjid (2016) untuk membahas perspektif cendikiawan muslim kontemporer tentang akuntansi dan akuntabilitas organisasional dalam Islam. Pandangan cendikiawan muslim dapat lebih tereksplorasi melalui wawancara mendalam semi terstruktur dan reviu terhadap berbagai dokumentasi relevan untuk menggali isu tersebut daripada menggunakan kuisioner yang telah disusun terlebih dahulu dengan skala tertentu.

\section{Proses Penelitian Kualitatif}

Desain penelitian dapat menjadi petunjuk arah bagi peneliti untuk menjalankan proses risetnya. Dengan demikian, desain penelitian akan berisi tahap demi tahap yang akan ditempuh untuk menjawab permasalahan penelitian. Namun, tidak semua studi kualitatif dimulai dengan memiliki sebuah desain riset (Yin, 2011). Untuk hal ini, desain bukan sebagai sebuah rencana untuk menjalankan studi, namun hanya sebagai fitur retrospektif dari studi. Pada riset kualitatif, proses desain riset bersifat rekursif, yang bermakna porsi desain dapat dapat direvisi lebih dari sekali dalam studi. Desain riset mengacu pada peningkatan kualitas melalui validitas studi. Untuk semua riset, termasuk kualitatif, kontrol kualitas mengacu pada validitas studi dan temuannya. Terdapat sejumlah strategi untuk memastikan validitas studi seperti rekaman wawancara dan transkripsi kata demi kata, mengikuti protokol wawancara menggunakan pertanyaan terbuka, triangulasi dengan jenis data dan pengujian kolega atas data selama analisis untuk membantu mengkonfirmasi temuan (Siccama dan Penna, 2008; Chawla, 2016).

\section{Teknik Pengumpulan data}


Sumber data utama dalam penelitian kualitatif yaitu kata-kata dan tindakan, sisanya adalah data tambahan seperti dokumen dan data lainnya (Moleong, 2005). Penelitian kualititatif umumnya tidak menggunakan instrumen baku, prosedur-prosedur atau sampel. Meskipun peneliti dapat mengadopsi sebuah instrumen mekanis untuk membantu proses pengumpulan data, peneliti tetap pada riset instrumen induk. Yin (2010,p.131) menjelaskan kegiatan pengumpulan data terdiri dari aktivitas wawancara, observasi, pengumpulan dan pengujian, dan perasaan, seperti dijelaskan pada tabel 1 sebagai berikut:

Tabel 1. Metoda pengumpulan data dan jenis data untuk riset kualitatif

\begin{tabular}{|c|c|c|}
\hline $\begin{array}{c}\text { Metoda } \\
\text { pengumpulan } \\
\text { data }\end{array}$ & Jenis ilustratif data & Contoh khusus data \\
\hline $\begin{array}{l}\text { Wawancara dan } \\
\text { perbincangan }\end{array}$ & $\begin{array}{ll}\text { Bahasa } & \text { (verbal dan } \\
\text { tubuh) }\end{array}$ & $\begin{array}{l}\text { Penjelasan orang lain tentang beberapa } \\
\text { prilaku dan tindakan; sebuah ingatan }\end{array}$ \\
\hline Observasi & $\begin{array}{l}\text { Gestur orang, interaksi } \\
\text { sosial, aksi, tempat } \\
\text { kejadian dan } \\
\text { lingkungan fisik }\end{array}$ & $\begin{array}{l}\text { Jumah dan sifat koordinasi antara dua } \\
\text { orang, pengaturan ruang }\end{array}$ \\
\hline Mengumpulkan & $\begin{array}{l}\text { Terdiri atas dokumen } \\
\text { personal, bahan } \\
\text { cetakan lain, grafik, } \\
\text { arsip, dan benda fisik. }\end{array}$ & $\begin{array}{l}\text { Judul, teks, tanggal, dan kronologis; } \\
\text { kata-kata tertulis lain, entri dalam } \\
\text { catatan arsip }\end{array}$ \\
\hline Perasaan (feeling) & Sensasi & $\begin{array}{l}\text { Dingin atau hangat suatu tempat, waktu } \\
\text { yang dirasakan, interpretasi } \\
\text { kenyamanan atau ketidaknyamanan } \\
\text { orang lain }\end{array}$ \\
\hline
\end{tabular}

Sumber: Yin, 2010

Wawancara memungkinkan peneliti mengumpulkan data yang bervariasi dari responden dari berbagai situasi dan konteks. Namun, wawancara perlu dilakukan dengan hati-hati dan membutuhkan triangulasi dengan data dari sumber lain. Jenis wawancara dapat digolongkan berdasarkan tingkat fromalitas dan terstrukturnya wawancara yaitu wawancara terstruktur, wawancara tidak terstruktur dan wawancara semi struktur (Saunders, Lewis \& Thornhill, 2016). 
Wawancara perlu dipersiapkan sebaik mungkin untuk menghindari pertanyaan yang bias, pertanyaan yang berulang, membingungkan dan tidak relevan, karena dapat mengganggu kualitas riset. Selain wawancara, pengumpulan data dapat dilakukan dengan observasi atau studi lapangan.

\section{Analisis Kualitatif}

Analisis data kualitatif umumnya bergerak melalui lima fase (Yin, 2010). Pertama, kompilasi data kedalam database formal yang membutuhkan kehatihatian dan pengorganisasian metodik dari data asli. Kedua, disassembling atau pembongkaran data dalam database. Pada fase ini data kompilasi dipilah kedalam bagian yang lebih kecil dan diberi kode. Prosedur ini dapat diulang berkali-kali sebagai bagian dari uji coba untuk menguji kode-kode. Dengam menggunakan tema substantif untuk mereorganisir bagian-bagian kecil itu kedalam kelompok yang berbeda dan mengurutkannya. Ketiga, reassembling, penyusunan ulang dan rekombinasi dilakukan dengan menggambarkan data secara grafis, atau menyusunnya kedalam daftar dan bentuk tabel. Fase kedua dan ketiga dapat belurang beberapa kali untuk mendapatkan yang diinginkan. Keempat, menggunakan materi yang disusun kembali untuk membentuk naratif baru beserta tabel dan grafik yang relevan. Kelima, fase penyimpulan. Fase ini seharusnya berkaitan dengan interpretasi pada fase keempat dan meneruskannya pada fase dalam siklus.

Untuk membantu menganalisis data kualititatif, software komputer dapat digunakan seperti ATLAS-ti5, Nvivo7, MAXqda2, HyperRESEARCH6, QDA Miner 2.0, Qualrus, dan Transana2 (Yin, 2010). Untuk mendukung meningkatkan validitas riset kualitatif, qualitative data analysis software (QDAS) seperti NVIVO oleh Siccama dan Penna (2008) menunjukkan keandalannya dalam pengkodean data dan validitas data.

\section{SIMPULAN}

Perkembangan publikasi penelitian kualitatif di jurnal terkemuka pada disiplin akuntansi dan manajemen, menunjukkan pertumbuhan yang signifikan 
meskipun publikasi penelitian kuantitatif masih menjadi yang paling luas digunakan.

Penelitian kualitatif telah memberi kebebasan dari batas-batas obsesi pengujian hipotesis deduktif, yang memungkinkan menginvestigasi isu-isu dan pertanyaan yang hingga kini terabaikan oleh paradigma penelitian dominan. Selalu ada ruang dan sudut pandang yang membutuhkan penelitian kualitatif, yang tidak dapat dipecahkan dengan penelitian kuantitatif. Pada perkembangan riset akuntansi saat ini, terdapat asimilasi ide-ide dari disiplin lainnya yang dapat selesaikan dengan riset kualitatif. Dalam menganalisis data kualitiatif umumnya mengacu pada lima fase yaitu kompilasi, disassembling, reassembling, penginterpretasian dan penyimpulan, yang pada tahap tertentu dapat diulang berkali-kali untuk mendapatkan hasil yang diinginkan untuk menjawab permasalahan.

\section{PUSTAKA ACUAN}

Basri,H., Nabiha, A.K.S., dan Madjid, M.S.A., 2016. Accounting and Accountability in Religious Organizations: an Islamic Contemporary Scholars' Perspective, Gadjah Mada International Journal of Business, Vol. 18, No.2: 2017-230

Basri, H., 2014. Using qualitative Research in Accounting and Management Studies: Not a New Agenda, Journal of US-China Public Administration, Vol. 11, No.10:831-838

Boadu, M. Dan Sorour, M.K., 2015. On utilizing grounded theory in business doctoral research: guidance on the research design, procedures, and challanges. International Journal of Doctoral Studies. Vol. 10, pp. 143-166.

Chawla, S.P.D., 2016. Using qualitative research for estabilishing content validity of e-lifestyle And Website Quality Constructs, Qualitative Market Research: An International Journal, Vo. 19 Iss. 3.

Cohanier, B., 2014. What Qualitative Research Can Tell Us About Performance Management Systems, Qualitative Research in Accounting \& Management, Vol.11 no.4 
Denyer, D., Tranfield, D., 2006. Using Qualitative Research Synstesis to Build an Actionable Knowledge Base, Management Decision, Vol.44, No.2:213-227

Fogarty, TJ. Dan Jones, D.E., 2014. Between a Rock And A Hard Place : How Tax Practisioners Straddle Client Advocacy And Professional Responsibilities, Qualitative Research in Accounting \& Management, Vol. 11 No.4.

Lee, B., Humphrey, C., 2006. More than a Numbers Game: Qualitative Research in Accounting, Management Decision, Vol.44 no.2:180-197

Moleong, L.Y., 2005. Metodologi Penelitian Kualitatif, Edisi Revisi, Bandung: PT Penerbit Remaja Rosdakarya.

Oever, K.V.D., \& Martin, X., 2015, Busines model change: managerial roles and tactics in decision making, Advance in Strategic Management, Vol.33. p.387-420.

Parker, L.D. 2008. Interpreting interpretive accounting research, Critical Perspectives on Accounting, Vol. 19. Pp. 909-1014

Parker, L., 2014. Qualitative perspectives: through a methodological lens, Qualitative Research in Accounting \& Management, Vol. 11 Iss.1: 13-28

Siccama, C. J., dan Penna, S., 2008. Enhancing Validity of a Qualitative Disertation Research Study by Using NVIVO, Qualitative Research Journal, Vol. 8. Iss.2:91-103

Stone, D.N., Nikitkov, A.N. dan Miller, T.C., 2015. Strategy, IT, and Control @eBay, 1925-2005: The Management Control System (MCS) as Consumer Product, Qualitative Research in Accounting \& Management. Vol.11 No.4.

Samkin, G., Shcneider, A., 2008. Adding Scientific Rigour to Qualitative Data Analysis: an Illustrative Example, Qualitative Research in Accounting \& Management. Vol.5 No.3:207-238.

Saunder, M., Lewis, P., \&Thornhill, A. 2016. Research Method For Business Students, 4th Ed., FT Prentice Hall, Harlow.

Trumbull, M. \& Watson, K., 2010. Qualitative research Method.Integrating quantitative and Qualitative Methods in Research, 3rd Ed.pp.62-78., USA. University Press of America, Inc.

Yin, R.K., 2011. Qualitative Research From Start to Finish, The Guilford Press. 